\title{
Uji efek perasan daging buah labu kuning (Cucurbita moschata D.) terhadap kadar kolesterol total darah tikus wistar (Rattus norvegicus)
}

\author{
${ }^{1}$ Lisa C. Ratulangi \\ ${ }^{2}$ Pemsi M. Wowor \\ ${ }^{2}$ Christi Mambo
}

\author{
${ }^{\mathbf{1}}$ Kandidat Skripsi Fakultas Kedokteran Universitas Sam Ratulangi Manado \\ ${ }^{2}$ Bagian Farmakologi dan Terapi Fakultas Kedokteran Universitas Sam Ratulangi Manado \\ Email: lisacr94@gmail.com
}

\begin{abstract}
This study aimed to obtain the effect of pumpkin fruit pulp (Cucurbita moschata D.) juice on total blood cholesterol of wistar rats (Rattus norvegicus). This was an experimental laboratory study conducted in the Laboratory of Pharmacology and Therapy Faculty of Medicine, University of Sam Ratulangi. Samples were 10 rats with an average body weight of $150 \mathrm{~g}$. Samples were divided into 5 groups, each group consisted of 2 rats: negative control group, only used standard food; propylthiouracil (PTU) treatment group; positive control group used simvastatin after PTU induced for 14 days; propylthiouracil (PTU) treatment group continued with standard food; and propylthiouracil (PTU) treatment group continued with pumpkin fruit pulp juice. Doses of the pumpkin fruit pulp juice were 0.93 $\mathrm{g} / \mathrm{ml} / \mathrm{day} / \mathrm{rat}$ as many as $2 \mathrm{ml} / \mathrm{day}$. The measurement of total blood cholesterol levels was on days 0,15 , and 22 by using Autocheck. Conclusion: The pumpkin fruit pulp juice had an effect in reducing total blood cholesterol levels in wistar rats.
\end{abstract}

Keywords: juice of pumpkin fruit pulp, total blood cholesterol, propylthiouracil.

\begin{abstract}
Abstrak: Penelitian ini bertujuan untuk mengetahui efek air perasan daging buah labu kuning (Cucurbita moschata D.) terhadap kadar kolesterol darah total pada tikus wistar (Rattus norvegicus). Jenis penelitian ini eksperimental laboratorik di Laboratorium Farmakologi dan Terapi Fakultas Kedokteran Universitas Sam Ratulangi. Subjek penelitian berupa tikus wistar jantan berjumlah 10 ekor dengan berat rata-rata 150 g yang dibagi kedalam 5 kelompok, masing-masing sebanyak 2 ekor, yaitu: kontrol negatif hanya menggunakan pakan standar; kelompok perlakuan propiltiourasil (PTU); kontrol positif menggunakan simvastatin setelah diinduksi PTU selama 14 hari; kelompok perlakuan pemberian PTU dilanjutkan dengan pakan standar; dan kelompok perlakuan pemberian PTU dilanjutkan dengan perasan daging buah labu kuning (Cucurbita moschata D.). Dosis perasan daging buah labu kuning yang diberikan $0.93 \mathrm{~g} / \mathrm{ml} /$ hari/ekor sebanyak $2 \mathrm{ml} /$ hari. Pengukuran kadar kolesterol darah total dilakukan pada hari ke 0, 15, dan 22 menggunakan alat pengukur Autocheck. Simpulan: Perasan daging buah labu kuning berefek menurunkan kadar kolesterol total pada tikus wistar.
\end{abstract}

Kata kunci: perasan daging buah labu kuning, kolesterol total darah, propiltiourasil.

Penyakit kardiovaskular merupakan penyebab kematian nomor satu di dunia Barat. Menurut American Heart Association, semakin banyak kematian yang disebabkan oleh penyakit kardiovaskular. Salah satu penyakit kardiovaskular yaitu penyakit jantung koroner. ${ }^{1}$

Menurut World Health Organization (WHO), pada tahun 2012 diperkirakan 17,5 juta orang meninggal karena penyakit kardiovaskular. $^{2}$ WHO memrediksi bahwa 
angka kematian akibat penyakit kardiovaskular akan mencapai 23.600.000 orang pada tahun 2030. ${ }^{3}$ Berdasarkan Data Riset Kesehatan Dasar 2013, prevalensi penyakit jantung koroner di Indonesia tahun 2013 sebesar 0,5\% atau diperkirakan sekitar 883.447 orang. $^{4}$

Penyakit Jantung Koroner (PJK) merupakan penyebab nomor satu di dunia. Terdapat banyak faktor risiko penyakit jantung koroner, antara lain faktor yang tidak dapat diubah dan faktor yang dapat diubah. Salah satu faktor yang dapat diubah yaitu dislipidemia/hiperkoles-terolemia. ${ }^{5}$

Dislipidemia adalah kelainan metabolisme lipid yang ditandai dengan peningkatan maupun penurunan fraksi lipid dalam plasma. Kelainan fraksi lipid yang utama adalah kenaikan kadar kolesterol total, kolesterol LDL, kenaikan kadar trigliserida serta penurunan kadar HDL. ${ }^{6}$

Terdapat banyak macam obat yang diproduksi industri farmasi, namun penggunaannya dalam jangka panjang dilaporkan mempunyai efek samping sehingga masyarakat memanfaatkan herbal untuk mengobati penyakit gangguan metabolik. Labu kuning (Cucurbita moschata D.) merupakan salah satu tanaman yang dapat digunakan untuk pengobatan. Labu kuning termasuk salah satu jenis tanaman makanan yang memiliki kandungan gizi yang cukup tinggi dan lengkap. ${ }^{7}$ Melihat kandungan gizinya, olahan dari labu kuning sangat baik dikonsumsi oleh anak - anak maupun orangtua. Lewat sejumlah penelitian yang dilakukan para ahli diketahui pula, labu kuning memiliki peranan penting dalam mencegah penyakit degeneratif seperti diabetes mellitus, aterosklerosis, jantung koroner, tekanan darah tinggi, bahkan bisa pula mencegah kanker. ${ }^{8}$

Berdasarkan data di atas maka peneliti tertarik untuk melakukan penelitian tentang uji efek perasan daging buah labu kuning (Cucurbita moschata D.) terhadap kadar kolesterol darah total pada tikus wistar (Rattus norvegicus).

\section{METODE PENELITIAN}

Jenis penelitian ini ialah eksperimental laboratorik yang dilakukan di Laboratorium Farmakologi dan Terapi Fakultas Kedokteran Universitas Sam Ratulangi Manado pada bulan September 2015 Februari 2016. Sampel ialah 10 ekor tikus wistar jantan dengan berat rata-rata $150 \mathrm{~g}$. Tahap-tahap penelitian ialah: persiapan bahan (tablet propiltiourasil @100mg, tablet simvastatin @10mg, aquades, perasan daging buah labu kuning, dan makanan (pellet) ayam/AD), pemeliharaan tikus wistar, penentuan dosis propiltiourasil (PTU) dan simvastatin, serta pemberian perasan daging buah labu kuning, dan pengukuran kadar kolesterol darah total.

Propiltiourasil dibuat dalam bentuk larutan dengan cara melarutkan $100 \mathrm{mg}$ PTU dalam $8 \mathrm{ml}$ pelarut (aquades). Jadi dalam $1 \mathrm{ml}$ larutan terkandung 12,5 mg PTU. Dosis propiltiourasil yang digunakan adalah 12,5 mg/hari dibagi dalam 2 kali pemberian dosis pemberian selama 14 hari. Jadi dosis yang diberikan sebanyak 1 cc/hari dengan 2 kali pemberian.

Dosis simvastatin yang digunakan pada orang dewasa dengan berat rata-rata $50 \mathrm{~kg}$ yaitu $40 \mathrm{mg} /$ hari. Dosis simvastatin yang digunakan pada tikus dengan berat 150 gram yaitu $150 / 50000$ x $40=0,12$ dibulatkan menjadi $0,1 \mathrm{mg}$. Simvastatin dibuat dalam bentuk larutan dengan cara melarutkan $10 \mathrm{mg}$ simvastatin dalam 100 ml pelarut (aquades), sehingga dalam $1 \mathrm{ml}$ terkandung $0,1 \mathrm{mg}$ simvastatin.

Hasil blender potongan kecil daging buah labu kuning diperas dan hasil perasan diberikan ke sampel dengan menggunakan sonde lambung. Dosis perasan daging buah labu kuning yang diberikan 0.93 $\mathrm{g} / \mathrm{ml} /$ hari/ekor sebanyak $2 \mathrm{ml} /$ hari.

Kadar kolesterol total darah diukur dari sampel darah kapiler segar yang diperoleh dengan cara memotong bagian ujung ekor tikus dengan gunting. Untuk mengukur kadar kolesterol total darah tersebut digunakan alat ukur kolesterol Autocheck.

\section{Perlakuan Hewan Uji}

Hewan uji terdiri dari 10 ekor tikus 
wistar jantan yang dibagi dalam 5 kelompok, yaitu:

1. Kelompok 1 sebagai kontrol negatif yang hanya diberikan pakan standar berupa pellet selama 14 hari.

2. Kelompok 2 sebagai kelompok yang diberikan propiltiourasil (PTU) selama 14 hari.

3. Kelompok 3 sebagai kontrol positif yang diberikan propiltiourasil (PTU) selama 14 hari, kemudian PTU dihentikan, dilanjutkan dengan simvastatin selama 7 hari.

4. Kelompok 4 sebagai kelompok yang diberikan propiltiourasil (PTU) selama 14 hari, kemudian PTU dihentikan, dilanjutkan dengan pakan standar selama 7 hari.

5. Kelompok 5 sebagai kelompok perlakuan yang diberikan propiltiourasil (PTU) selama 14 hari, kemudian PTU dihentikan, dilanjutkan dengan perasaan daging buah labu kuning selama 7 hari.

\section{Analisis data}

Data disajikan secara deskriptif komparatif dengan menilai hasil pemeriksaan kadar kolesterol total antara kelompok 1, 2, 3, 4 dan 5.

\section{HASIL PENELITIAN}

\section{Kadar Kolesterol Total Tikus Wistar Kelompok 1 Kontrol Negatif}

Tabel 1. Kadar Kolesterol Total Kelompok 1

\begin{tabular}{ccc}
\hline $\begin{array}{c}\text { KKelompok 1 } \\
\text { Kontrol }(-)\end{array}$ & $\begin{array}{c}\text { Hari ke }-0 \\
(\mathrm{mg} / \mathrm{dl})\end{array}$ & $\begin{array}{c}\text { Hari ke }-15 \\
(\mathrm{mg} / \mathrm{dl})\end{array}$ \\
\hline Tikus 1 & 107 & 110 \\
Tikus 2 & 109 & 114 \\
Rata - rata & 108 & 112 \\
\hline
\end{tabular}

\section{Kelompok 2 Perlakuan Pemberian PTU}

Tabel 2. Kadar Kolesterol Total Kelompok 2

\begin{tabular}{ccc}
\hline Kelompok 2: & $\begin{array}{c}\text { Hari ke }-0 \\
(\mathrm{mg} / \mathrm{dl})\end{array}$ & $\begin{array}{c}\text { Hari ke }-15 \\
(\mathrm{mg} / \mathrm{dl})\end{array}$ \\
\hline Tikus 1 & 104 & 165 \\
Tikus 2 & 111 & 154 \\
Rata - rata & 107,5 & 159,5 \\
\hline
\end{tabular}

Kelompok 3 Kontrol Positif

Tabel 3. Kadar Kolesterol Total Kelompok 3

\begin{tabular}{cccc}
\hline $\begin{array}{c}\text { Kelompok 3 } \\
\text { Kontrol(+) }\end{array}$ & $\begin{array}{c}\text { Hari } \\
\text { ke- } 0 \\
(\mathrm{mg} / \mathrm{dl})\end{array}$ & $\begin{array}{c}\text { Hari } \\
\mathrm{ke}-15 \\
(\mathrm{mg} / \mathrm{dl})\end{array}$ & $\begin{array}{c}\text { Hari } \\
\mathrm{ke}-22 \\
(\mathrm{mg} / \mathrm{dl})\end{array}$ \\
\hline Tikus 1 & 109 & 156 & 151 \\
Tikus 2 & 107 & 149 & 142 \\
Rata- rata & 108 & 152,5 & 146,5 \\
\hline
\end{tabular}

Kelompok 4 Pemberian PTU dilanjutkan dengan Pakan Standar

Tabel 4. Kadar Kolesterol Total Kelompok 4

\begin{tabular}{cccc}
\hline Kelompok 4 & $\begin{array}{c}\text { Hari ke- } \\
0 \\
(\mathrm{mg} / \mathrm{dl})\end{array}$ & $\begin{array}{c}\text { Hari ke- } \\
15 \\
(\mathrm{mg} / \mathrm{dl})\end{array}$ & $\begin{array}{c}\text { Hari ke- } \\
22 \\
(\mathrm{mg} / \mathrm{dl})\end{array}$ \\
\hline Tikus 1 & 125 & 162 & 160 \\
Tikus 2 & 105 & 150 & 150 \\
Rata- rata & 115 & 156 & 155 \\
\hline
\end{tabular}

Kelompok 5 Perlakuan Pemberian PTU dilanjutkan dengan Perasan Daging Buah Labu Kuning

Tabel 5. Kadar Kolesterol Total Kelompok V

\begin{tabular}{clll}
\hline $\begin{array}{c}\text { Kelompok } \\
5\end{array}$ & $\begin{array}{l}\text { Hari } \\
\text { ke- } 0 \\
(\mathrm{mg} / \mathrm{dl})\end{array}$ & $\begin{array}{l}\text { Hari } \\
\text { ke- 15 } \\
(\mathrm{mg} / \mathrm{dl})\end{array}$ & $\begin{array}{l}\text { Hari } \\
\text { ke- 22 } \\
(\mathrm{mg} / \mathrm{dl})\end{array}$ \\
\hline Tikus 1 & 104 & 174 & 152 \\
Tikus 2 & 107 & 159 & 138 \\
Rata -rata & 105,5 & 166,5 & 145 \\
\hline
\end{tabular}

\section{BAHASAN}

Dalam penelitian ini diamati efek pemberian perasan daging buah labu kuning terhadap penurunan kadar kolesterol total tikus wistar. Dengan pemberian perasan daging buah labu kuning diharapkan kadar kolesterol total dapat diturunkan.

Hasil pengujian pada kelompok 1 sebagai kontrol negatif yang tidak diberikan perlakuan hanya diberikan pakan standar didapatkan hasil rata-rata kadar kolesterol total pada hari ke 15 yaitu 112 $\mathrm{mg} / \mathrm{dl}$. Hal ini berarti dengan pemberian pakan standar tidak ada perubahan bermakna pada kadar kolesterol total. 
Berbeda dengan hasil pengujian pada kelompok 2 yang hanya diberikan PTU selama 14 hari didapatkan hasil kadar kolesterol total rata-rata pada hari ke 15 yaitu 159,5 mg/dl mengalami kenaikan kadar kolesterol total. Hal ini berarti PTU dapat menyebabkan hiperkolesterolemia. PTU berfungsi meningkatkan kadar kolesterol dengan cara menghambat sintesis hormon tiroid. Peningkatan hormon tiroid dapat menurunkan kadar kolesterol dengan cara meningkatkan kadar sekresi kolesterol menuju empedu dan selanjutnya dibuang bersama feses. Mekanisme penurunan kadar kolesterol oleh hormon tiroid yaitu hormon tiroid menginduksi peningkatan jumlah reseptor LDL pada selsel hepar menyebabkan pembuangan yang cepat (Rapid removal) LDL dari plasma oleh hati, dimana kolesterol yang tadinya ada pada LDL disekresi lewat empedu menuju feses, sehingga menginduksi terjadinya peningkatan kadar kolesterol total. ${ }^{9,10}$

Hasil pengujian pada kelompok 3 sebagai kontrol positif yang diberikan PTU selama 14 hari, kemudian PTU dihentikan, dilanjutkan dengan simvastatin selama 7 hari menunjukkan penurunan kadar kolesterol total. Hal ini berarti simvastatin dapat menyebabkan hipolipidemik. Statin bekerja dengan cara menghambat sintesis kolesterol dalam hati dengan menghambat enzim HMG KoA reduktase. Akibat penurunan sintesis kolesterol ini, maka SREBP (Sterol regulatory element binding protein) yang terdapat pada membran dipecah oleh protease lalu diangkut ke nukleus. Faktor-faktor transkripsi akan berikatan dengan gen reseptor LDL sehingga terjadi peningkatan sintesis reseptor LDL. Peningkatan reseptor LDL pada membran sel hepatosit akan menurunkan kadar kolesterol darah. ${ }^{11}$

Hasil pengujian kelompok 4 yaitu kelompok yang diberikan PTU selama 14 hari didapatkan kadar kolesterol total ratarata sebesar $156 \mathrm{mg} / \mathrm{dl}$, dan PTU dihentikan, dilanjutkan dengan pakan standar selama 7 hari didapatkan hasil kadar kolesterol total rata-rata sebesar 155 mg/dl, terlihat bahwa kelompok ini tidak meningkatkan kadar kolesterol total. Hal ini berarti pakan yang tidak memiliki efek dalam meningkatkan kadar kolesterol total.

Hasil pengujian pada kelompok 5 ialah kelompok perlakuan yang diberikan PTU selama 14 hari, kemudian PTU dihentikan, dilanjutkan dengan perasan daging buah labu kuning selama 7 hari didapatkan hasil kadar kolesterol total rata-rata pada hari ke 22 yaitu $145 \mathrm{mg} / \mathrm{dl}$ menunjukkan penurunan kadar kolesterol total yang tidak begitu besar. Hasil penelitian ini menunjukkan bahwa perasan daging buah labu kuning mempunyai sedikit pengaruh terhadap efek penurunan kadar kolesterol total. Pada penelitian sebelumnya oleh Ika Lusia Agustin tahun 2008 juga menggunakan labu kuning diperoleh hasil labu kuning mampu menurunkan kadar kolesterol total. Bedanya dengan penelitian ini, digunakan perasan daging buah labu kuning. Pada prinsipnya hasil yang didapatkan pada kedua penelitian ini sama - sama diperoleh efek menurunkan kadar kolesterol total. ${ }^{12}$ Penurunan kadar kolesterol total yang tidak begitu besar pada penelitian ini mungkin dikarenakan waktu penelitian yang kurang panjang. Kemungkinan penurunan kolesterol total setelah pemberian perasan daging buah labu kuning disebabkan oleh kandungan yang terdapat dalam labu kuning seperti beta karoten, dimana kandungan labu kuning mengandung beta karoten yang tinggi. ${ }^{8}$ Hal tersebut disebabkan oleh aktivitas beta karoten yang dapat mencegah terjadinya plak / timbunan kolesterol di dalam pembuluh darah. ${ }^{13}$ Beta karoten dikatakan memiliki fungsi sebagai scavenger radikal bebas di mana beta karoten melindungi membran lipid dari reaksi peroksidasi, dan sekaligus menghentikan reaksi rantai dari radikal bebas. $^{14}$

\section{SIMPULAN}

Dari penelitian yang telah dilakukan dapat disimpulkan, pemberian perasan daging buah labu kuning (Cucurbita moschata D.) dengan lama pemberian 
selama 7 hari pada tikus wistar jantan dengan kadar kolesterol total tinggi akibat induksi PTU sedikit berpengaruh terhadap penurunan kadar kolesterol total.

\section{SARAN}

1. Perlu diadakan penelitian lanjut dengan waktu penelitian yang lebih panjang.

2. Perlu diadakan penelitian lanjut tentang kandungan dalam daging buah labu kuning yang memengaruhi kadar kolesterol darah total.

\section{DAFTAR PUSTAKA}

1. Price SA, Wilson LM. Patosfisiologi (6th ed). Jakarta: EGC, 2005:51.

2. World Health Organization. Cardiovascular diseases (CVDs). [cited 2015 Sep 20]. Available from: http://www.who.int/mediacentre/facts heets/fs317/en/

3. World Health Organization. Cardiovascular diseases (CVDs). [cited 2015 Okt 21]. Available from: http://www.who.int/cardiovascular_d iseases/about_cvd/en/

4. Pusat Data dan Informasi Kementerian Kesehatan RI. Situasi Kesehatan Jantung. [cited 2015 Sep 20]. Available from: http://www.pusdatin.kemkes.go.id

5. Perhimpunan Dokter Spesialis Kardiovaskular Indonesia 2013. Pedoman Tatalaksana Dislipdemia. 2013. [cited 2016 Jan 10]. Available from:

http://www.inaheart.org/upload/file/P edoman_tatalksana_Dislipidemia.pdf

6. Anwar TB. Dislipidemia sebagai faktor resiko penyakit jantung koroner. [cited tanggal 8 Januari 2016]. Available from: http://www.repository.usu.ac.id/bitstr eam/123456789/3503/1/gizibahri3.pd $\mathrm{f}$.

7. Sudarto Y, Budidaya W. Yogyakarta: Kanisius, 1993.

8. Brotodjojo LC. Semua Serba Labu Kuning. Jakarta: Penerbit PT Gramedia Pustaka Utama, 2010; p. 6.

9. Suherman SK, Elysabeth. Hormon Tiroid dan Antitiroid. In: Farmakologi dan Terapi. Ed.5. Jakarta: FKUI, 2007; p. 441-2.

10. Guyton AC, Hall JE. Endokrinologi dan Reproduksi. In: Buku Ajar Fisiologi Kedokteran (11th ed). Jakarta: EGC, 2007; p. 987.

11.Suyatna FD. Hipolipidemik. In: Gunawan, Sulistia, editor. Farmakologi dan Terapi (5th ed). Jakarta: FKUI, 2007; p. 374, 376, 383, 384.

12.Trubus Info Kit. 100 Plus Herbal Indonesia Bukti Ilmiah dan Racikan. Vol 11. Depok: PT Trubus Swadaya, 2013; p. 374-7.

13.Astawan M, Kasih AL. Khasiat WarnaWarni Makanan. Jakarta: Penerbit PT Gramedia Pustaka Utama, 2008; p. 103.

14.Adrianta KA. Ekstrak Etanol Bunga Kenanga (Cananga odorata) Menurunkan Kadar Tumor Necrosis Faktor Alpha (TNF- $\alpha)$ dan Memperbaiki Profil Lipid pada Tikus Putih (Rattus norvegicus) yang Dislipidemia. Denpasar: UNUD; 2013. P. 35. 